Supplement of Atmos. Chem. Phys., 19, 499-521, 2019

https://doi.org/10.5194/acp-19-499-2019-supplement

(c) Author(s) 2019. This work is distributed under

the Creative Commons Attribution 4.0 License.

(c) (i)

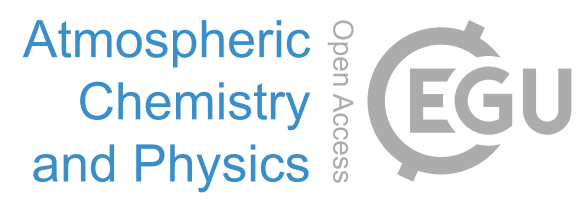

Supplement of

\title{
Volatile organic compounds and ozone in Rocky Mountain National Park during FRAPPÉ
}

Katherine B. Benedict et al.

Correspondence to: Katherine B. Benedict (katherine.benedict@ colostate.edu)

The copyright of individual parts of the supplement might differ from the CC BY 4.0 License. 


\section{More detailed methods:}

\section{In situ GC}

The VOC analytical system was similar to those used in previous studies (Abeleira et al., 2017; Sive et al., 2005) and utilized a Qdrive 2s102K cryocooler (Chart, Inc., Troy, NY) that was capable of cooling a sample enrichment loop from 100

$5{ }^{\circ} \mathrm{C}$ to $-180^{\circ} \mathrm{C}$ in 25 minutes for sample concentration. The loop was made from a 4 inch $\times 3 / 16$ inch piece of stainless steel tubing and filled with $1 \mathrm{~mm}$ diameter deactivated glass beads (Ohio Valley, Marietta, OH) to provide an inert area for sample concentration during the trapping stage. The loop was heated to $100{ }^{\circ} \mathrm{C}$ during the desorption, injection, and bake out stages of the system.

The trapping procedure was initiated when the sample enrichment loop reached its initial set point temperature (-180

$\left.10{ }^{\circ} \mathrm{C}\right)$. A $1000 \mathrm{~cm}^{3}$ aliquot of ambient air was sampled through a heated stainless steel inlet line $\left(70{ }^{\circ} \mathrm{C}\right)$ to remove $\mathrm{O}_{3}$ prior to the sample passing through the enrichment loop at a rate of $200 \mathrm{~cm}^{3} \mathrm{~min}^{-1}$. After the ambient air trapping procedure was completed, $100 \mathrm{~cm}^{3}$ of ultra-high purity (UHP) helium was passed through the loop at a rate of $100 \mathrm{~cm}^{3} \mathrm{~min}^{-1}$. The helium sweep was used to remove any residual $\mathrm{O}_{3}$, because condensed phase chemistry with $\mathrm{O}_{3}$ may occur before or during desorption (Koppmann et al., 1995). After the helium sweep was completed, the sample enrichment loop was isolated, and rapidly heated

15 to $100{ }^{\circ} \mathrm{C}$. Once the desorption temperature was reached, the sample was injected, and the GCs were triggered to start the temperature programs. UHP helium carrier gas flushed the contents of the sample enrichment loop through a $0.53 \mathrm{~mm}$ i.d. Silonite-coated transfer line to the splitter box. At the splitter box, the sample was quantitatively and reproducibly split into four sample sub-streams. Each of the four sub-streams was transferred to a separate GC separation column/detector pair.

Two Shimadzu GC-17A gas chromatographs (Shimadzu Scientific, Columbia, MD) each housed two different

20 separation columns. One $50 \mathrm{~m} \times 0.53 \mathrm{~mm}$ i.d., $10 \mu \mathrm{m}$ film thickness $\mathrm{CP}-\mathrm{Al}_{2} \mathrm{O}_{3} / \mathrm{Na}_{2} \mathrm{SO}_{4}$ PLOT column, one $60 \mathrm{~m} \times 0.32 \mathrm{~mm}$ i.d., $1 \mu \mathrm{m}$ film thickness VF-1ms column, one $60 \mathrm{~m} \times 0.25 \mathrm{~mm}$ i.d., $3 \mu \mathrm{m}$ film thickness CP-PoraBond Q column, and one 60 $\mathrm{m} \times 0.25 \mathrm{~mm}$ i.d., $1.0 \mu \mathrm{m}$ film thickness VF-1701 column (Varian Inc.) were used for trace gas separation. The PLOT, VF1ms, and PoraBond Q columns were each connected to a Flame Ionization Detector (FID) for analysis of $\mathrm{C}_{2}-\mathrm{C}_{7}$ and $\mathrm{C}_{6}$ - $\mathrm{C}_{10}$ non-methane hydrocarbons (NMHC), and selected oxidized VOCs (OVOCs: methanol, ethanol, acetaldehyde, acetone and 
MEK) measurements, respectively. The VF-1701 column was plumbed into an Electron Capture Detector (ECD) and used for measuring $\mathrm{C}_{1}-\mathrm{C}_{2}$ halocarbons and $\mathrm{C}_{1}-\mathrm{C}_{5}$ alkyl nitrates.

Two different whole air standards were alternately analysed every 10 samples throughout the campaign. The measurement precision, represented by the relative standard deviation (RSD) of the peak areas for each compound in the standards, was 1-

$58 \%$ for the NMHCs, 3-11\% for halocarbons, and 3-5\% for alkyl nitrates. A list of VOCs measured during this study using the in situ GC is shown in Table 1.

\section{Canister GC System}

The analytical system and methodology used for this study are similar to those used in previous studies (Russo et al., 2010; Sive, 1998; Zhou et al., 2010). For each sample, a $1265 \mathrm{~cm}^{3}$ (STP) aliquot of air was trapped on a glass bead filled loop

10 immersed in liquid nitrogen. After the sample was trapped, the loop was isolated, warmed to $80^{\circ} \mathrm{C}$ and injected. The carrier gas (UHP helium) flushed the contents of the loop and the stream was split into five, with each sub-stream feeding a separate GC column/detector pair as follows: (1) a CP- $\mathrm{Al}_{2} \mathrm{O}_{3} / \mathrm{Na}_{2} \mathrm{SO}_{4}$ PLOT column (Varian-Chrompack; $50 \mathrm{~m} \times 0.53 \mathrm{~mm}$ i.d., $10 \mu \mathrm{m}$ film thickness) connected to an FID was used to measure $\mathrm{C}_{2}$ - $\mathrm{C}_{7}$ NMHCs; (2) a VF-1ms column (Varian-Chrompack; 60m × $0.32 \mathrm{~mm}$ i.d., $1 \mu \mathrm{m}$ film thickness) connected to a FID measured $\mathrm{C}_{4}-\mathrm{C}_{10}$ NMHCs; (3) a CP-PoraBond Q column (Varian-

15 Chrompack; $25 \mathrm{~m} \times 0.25 \mathrm{~mm}$ i.d., $3 \mu \mathrm{m}$ thickness) coupled to a Restek XTI-5 column (Restek; $30 \mathrm{~m} \times 0.25$ mm i.d., $0.25 \mu \mathrm{m}$ film thickness) connected to an FID was used to measure selected OVOCs; (4) an OV-1701 column (Ohio Valley Specialty Chemical; $60 \mathrm{~m} \times 0.25 \mathrm{~mm}$ i.d. $1 \mu \mathrm{m}$ thickness) connected to an ECD was used to measure $\mathrm{C}_{1}-\mathrm{C}_{5}$ alkyl nitrates and $\mathrm{C}_{1}-\mathrm{C}_{2}$ halocarbons; (5) and an OV-624 column (Ohio Valley Specialty Chemical; $60 \mathrm{~m} \times 0.25 \mathrm{~mm}$ i.d., $1.4 \mu \mathrm{m}$ thickness) connected to an MS measured $\mathrm{C}_{6}-\mathrm{C}_{10}$ NMHCs, $\mathrm{C}_{1}-\mathrm{C}_{2}$ halocarbons, and was used to measure select OVOCs and reduced sulphur 20 compounds.

\section{Trail Ridge Road Ozone Calibrations}

Calibrations of the POMS unit were consistent with the US EPA guidance and were performed at Air Resource Specialists, Inc. (ARS) immediately prior to deployment and again after the campaign. The calibrations were performed by comparing the instrument output to an ultraviolet (UV) photometer transfer standard that is traceable to EPA. The instruments were 
challenged at multiple $\mathrm{O}_{3}$ concentrations (including zeros) and evaluated by the acceptance criteria which includes the percent difference of the analyser's response during the multipoint challenges and the instrument's linearity. The ARS calibration acceptance criteria for $\mathrm{O}_{3}$ is $\leq 3 \%$ for the multipoint challenges and $\leq 1 \%$ for the linearity. Further details regarding the calibrations of the $\mathrm{O}_{3}$ and meteorological measurements can be found in the Gaseous Pollutant Monitoring Program 2015

5 Quality Assurance Project Plan (https://ard-request.air-resource.com/Project/documents.aspx). 


\section{Details for calculating air mass photochemical age}

The dominant source of alkyl nitrates is the photochemical production from hydrocarbons. Equations 1-6 show the chemical mechanism for alkyl nitrate production.

5

10

$$
\begin{aligned}
& \mathrm{RH}+\mathrm{OH} \rightarrow \mathrm{R}+\mathrm{H}_{2} \mathrm{O}\left(k_{1}, \alpha_{1}\right) \\
& \mathrm{R}+\mathrm{O}_{2} \rightarrow \mathrm{RO}_{2}\left(k_{2}\right) \\
& \mathrm{RO}_{2}+\mathrm{NO} \rightarrow \mathrm{RO}^{2} \mathrm{NO}_{2}\left(k_{3}, 1-\alpha_{4}\right) \\
& \mathrm{RO}_{2}+\mathrm{NO} \rightarrow \mathrm{RONO}_{2}\left(k_{4}, \alpha_{4}\right) \\
& \mathrm{RONO}_{2}+h v \rightarrow \mathrm{RO}+\mathrm{NO}_{2}\left(j_{5}\right) \\
& \mathrm{RONO}_{2}+\mathrm{OH} \rightarrow \text { products }\left(k_{6}\right)
\end{aligned}
$$

$k_{1}, k_{2}, k_{3}, k_{4}, k_{6}$ are reaction rate constants, $\alpha_{1}$ and $\alpha_{4}$ are the reaction branching rates and $j_{5}$ is the photolysis rate constant.

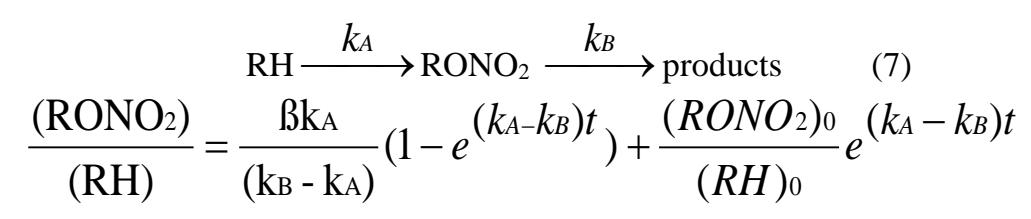

$15 k_{A}=\mathrm{k}_{1}[\mathrm{OH}], k_{B}=\mathrm{k}_{6}[\mathrm{OH}]+\mathrm{J}_{5}, ß=\alpha_{1} \alpha_{4},\left(\mathrm{RONO}_{2}\right)_{\mathrm{o}} /(\mathrm{RH})_{\mathrm{o}}$ is the initial alkyl nitrate/parent hydrocarbon ratio. If $\left(\mathrm{RONO}_{2}\right)_{0}$ $/(\mathrm{RH})_{\mathrm{o}}=0$, the solution to equation describes the time evolution of the alkyl nitrate/parent hydrocarbon ratio based solely on gas phase hydrocarbon chemistry (Bertman et al., 1995). 


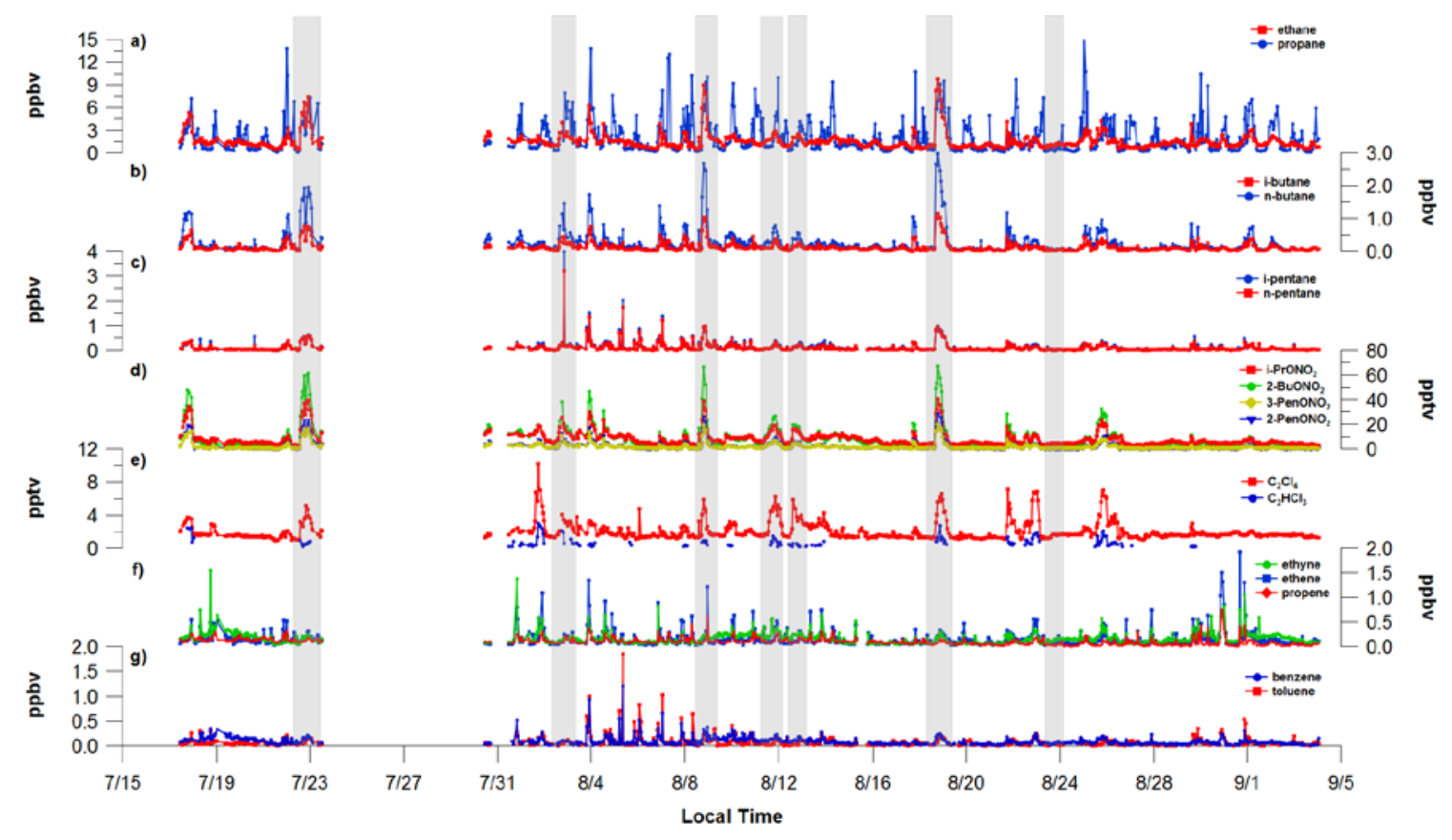

Figure S1 Time series of VOCs measured at a ROMO site during FRAPPÉ. a) ethane and propane, b) i-butane and n-butane, c) i-

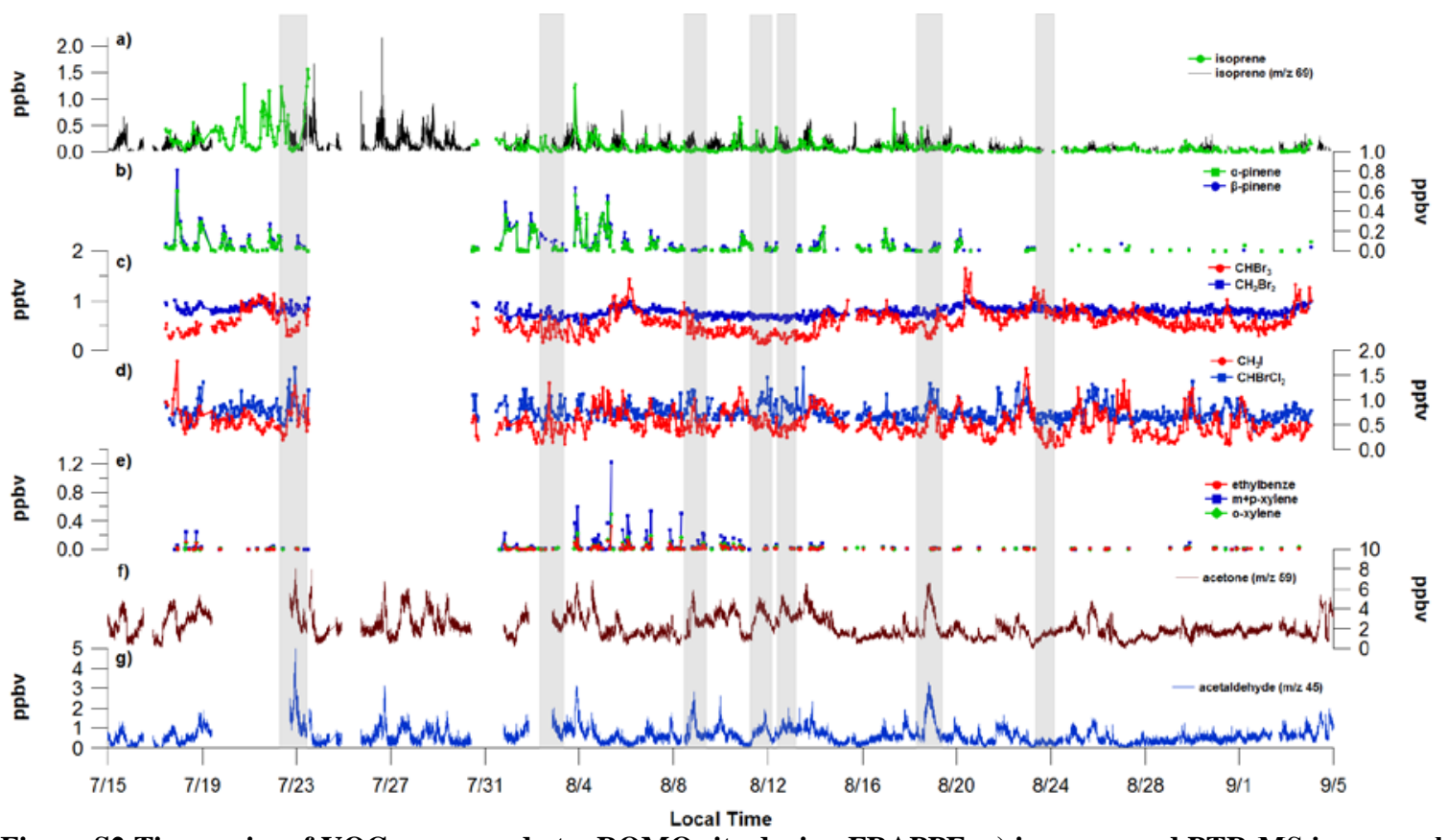

Figure S2 Time series of VOCs measured at a ROMO site during FRAPPE. a) isoprene and PTR-MS isoprene, b) $\alpha$-pinene and $\beta$ pinene, c) $\mathrm{CHBr}_{3}$ and $\mathrm{CH}_{2} \mathrm{Br}_{2}$, d) $\mathrm{CH}_{3} \mathrm{I}$ and $\mathrm{CHBrCl}_{2}$, e) ethylbenzene, m+p-xylene, o-xylene, f) acetone, g) acetaldehylde 


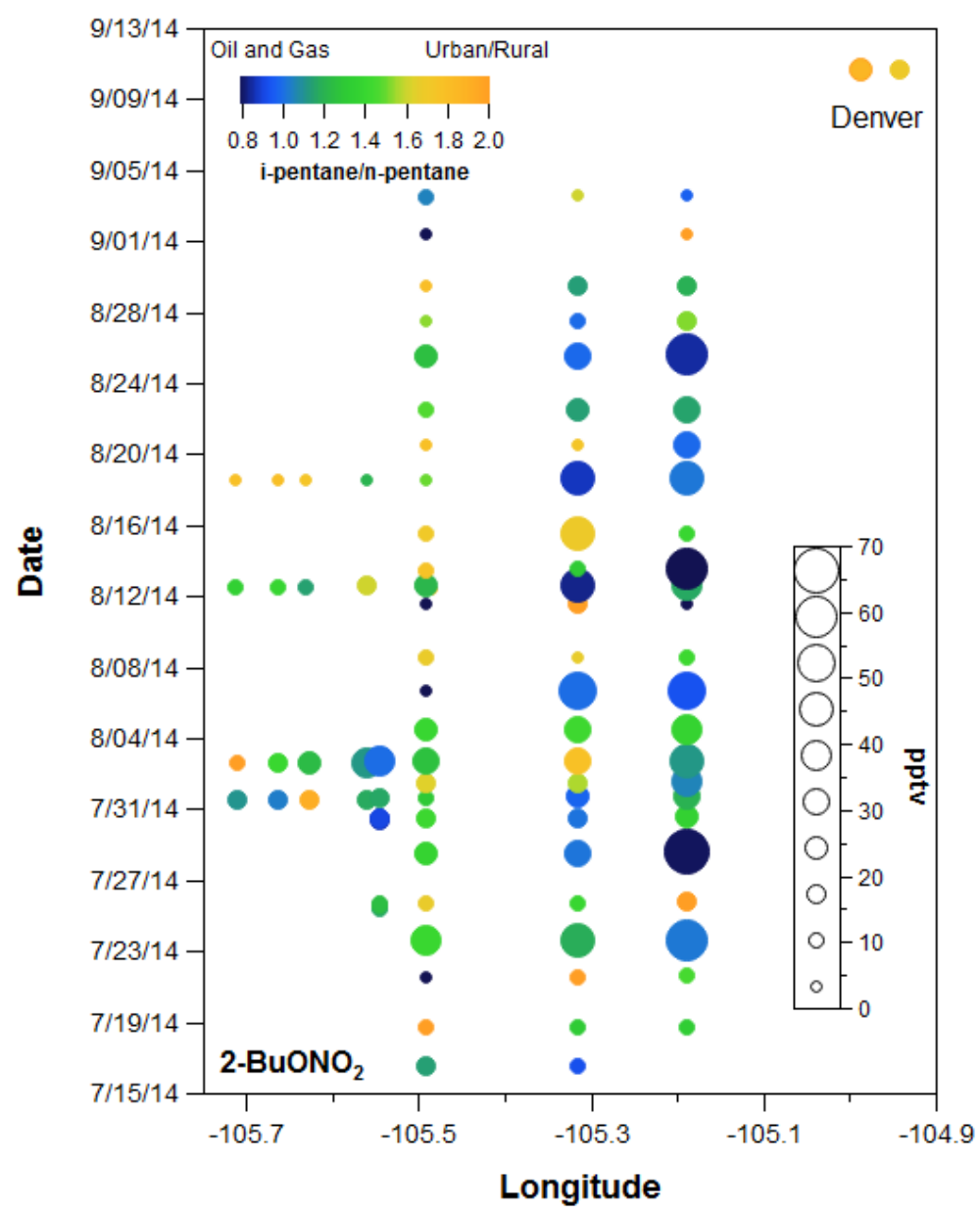

Figure S3a. VOC canister data plotted by longitude and date with 2-BuONO $\mathrm{O}_{2}$ mixing ratio represented by the size of each point and the i- to n-pentane represented by the colour. Locations correspond to transect samples shown in Figure 2. 


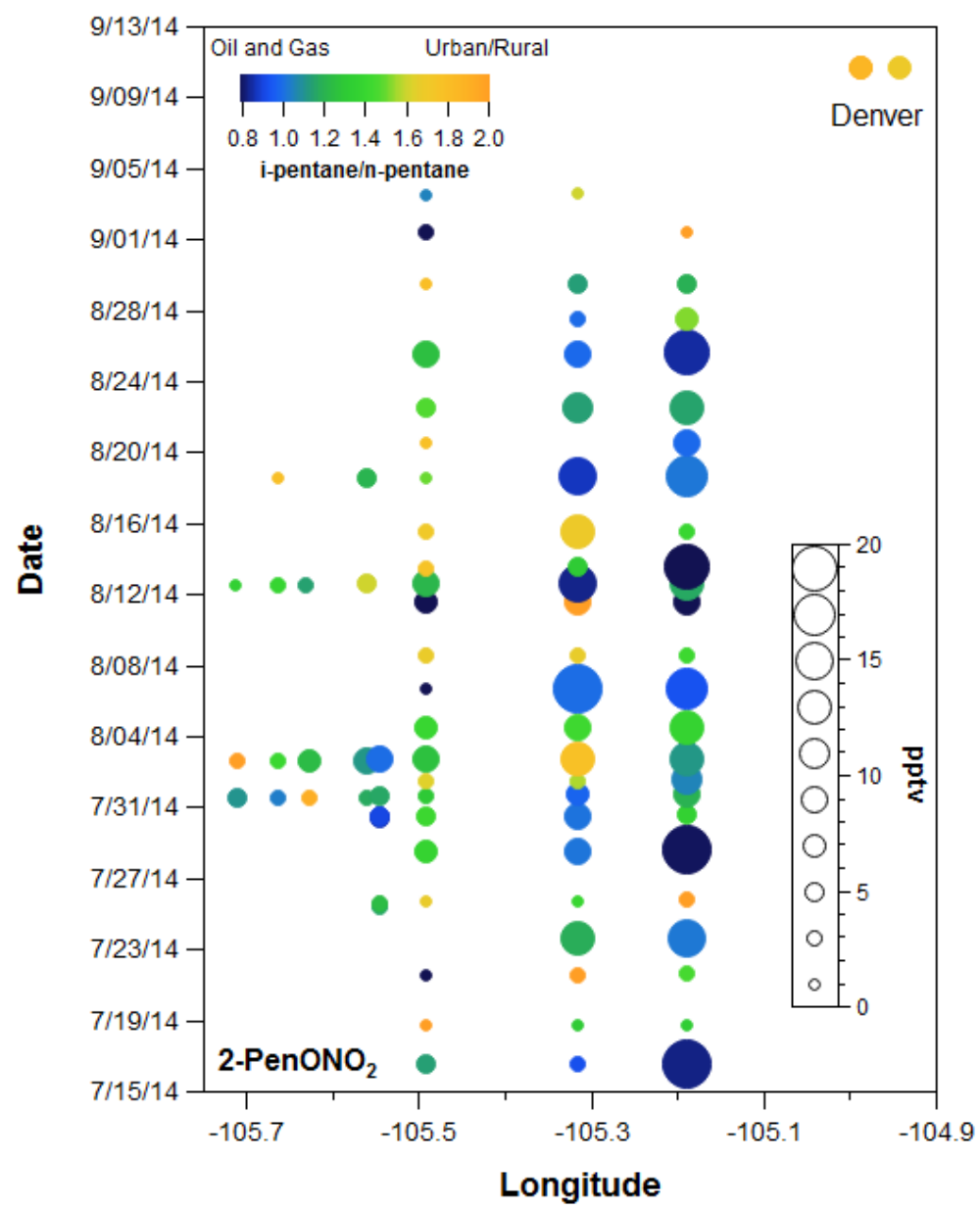

Figure S3b. VOC canister data plotted by longitude and date with 2-PenONO 2 mixing ratio represented by the size of each point and the i- to n-pentane represented by the colour. Locations correspond to transect samples shown in Figure 2. 


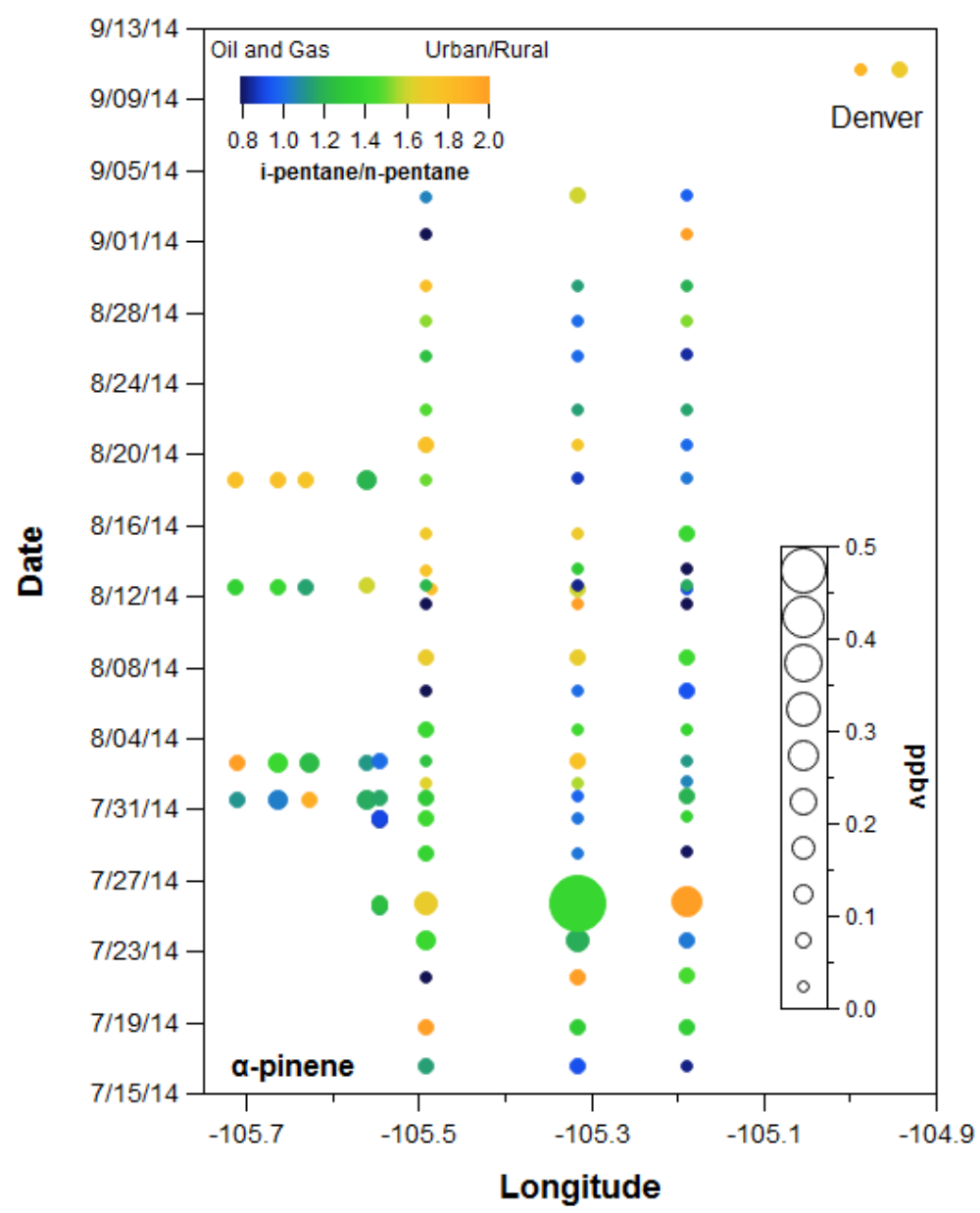

Figure S3c. VOC canister data plotted by longitude and date with $\alpha$-pinene mixing ratio represented by the size of each point and the i- to n-pentane represented by the colour. Locations correspond to transect samples shown in Figure 2. 


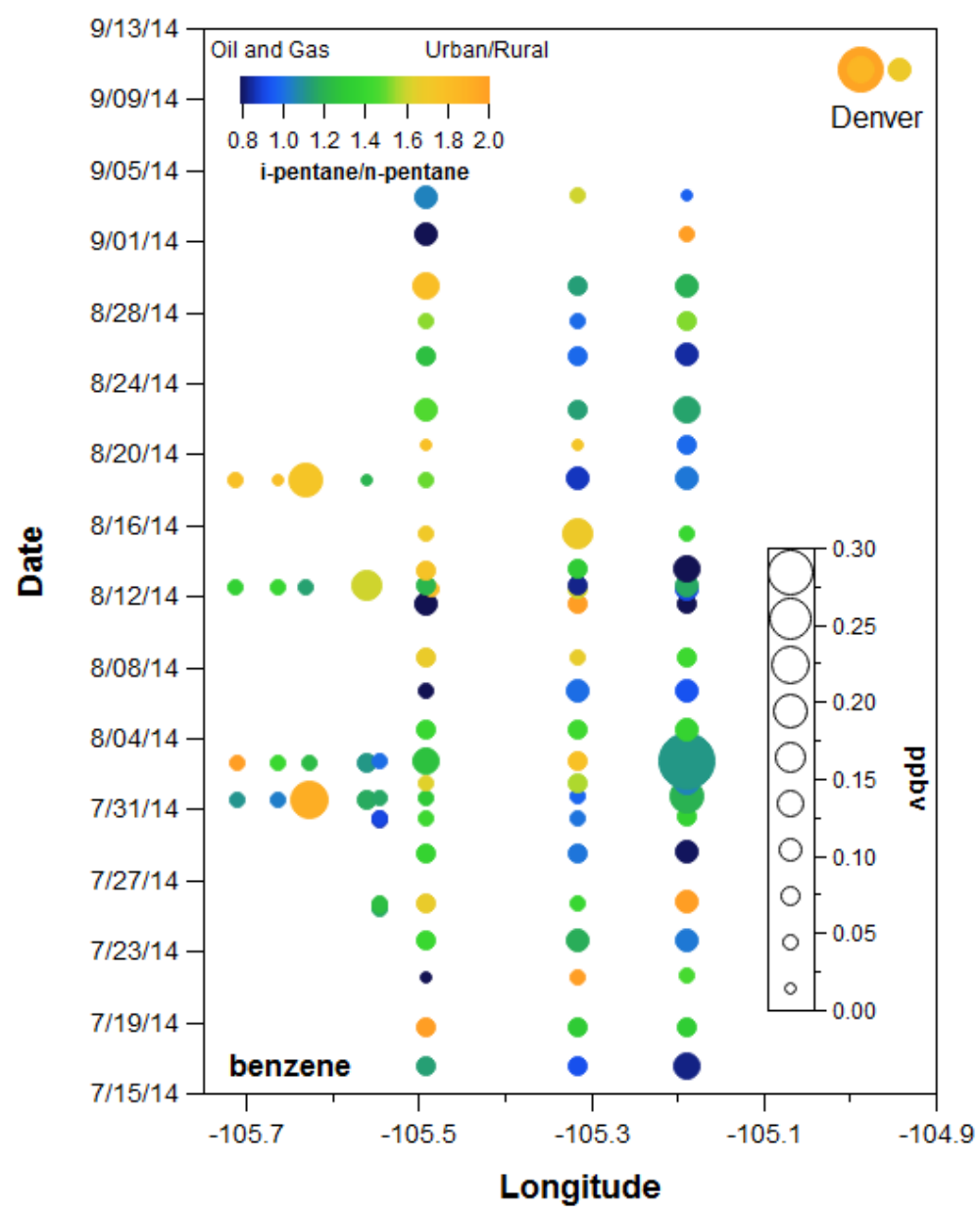

Figure S3d. VOC canister data plotted by longitude and date with benzene mixing ratio represented by the size of each point and the i- to n-pentane represented by the colour. Locations correspond to transect samples shown in Figure 2. 


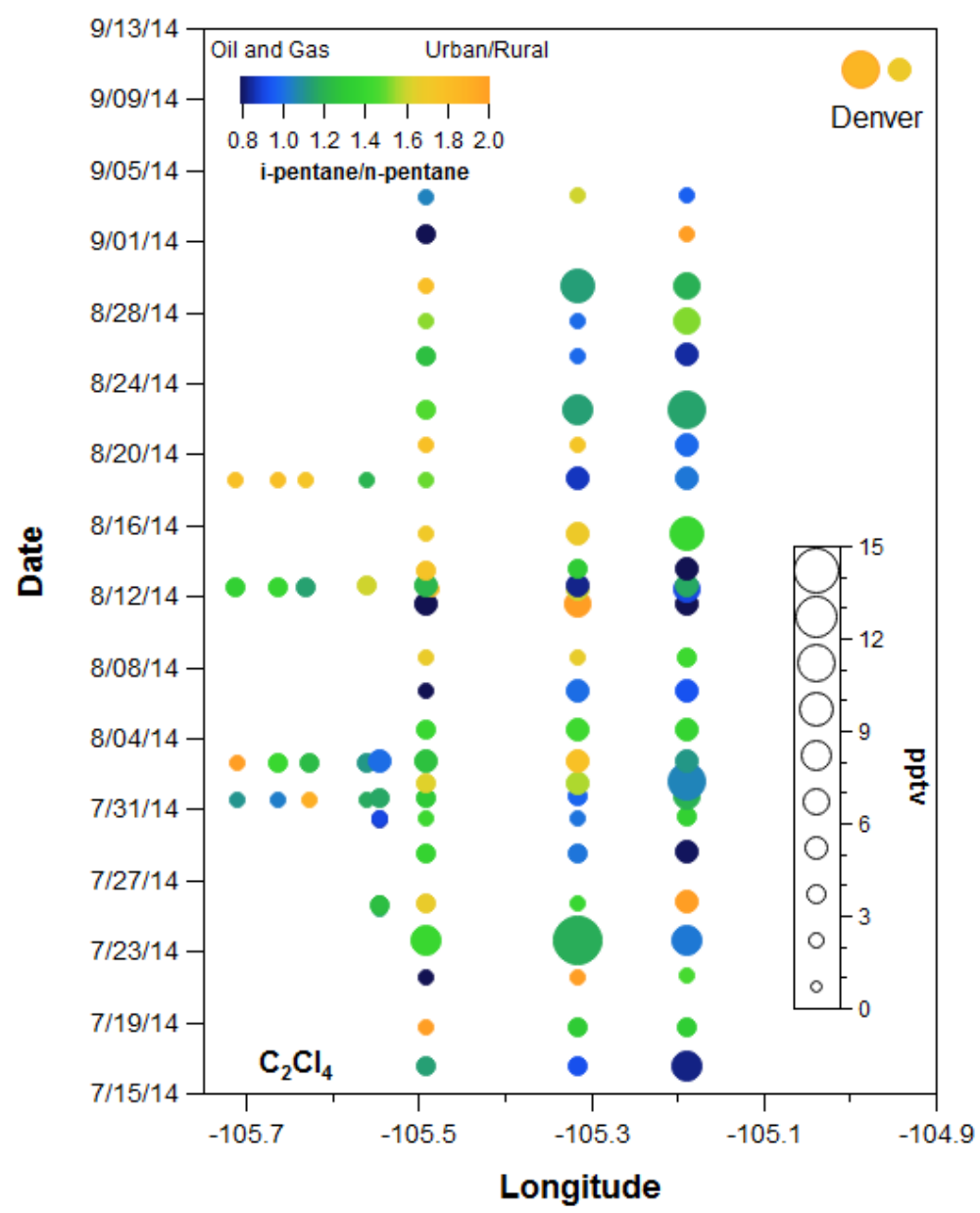

Figure S3e. VOC canister data plotted by longitude and date with $\mathrm{C}_{2} \mathrm{Cl}_{4}$ mixing ratio represented by the size of each point and the i- to n-pentane represented by the colour. Locations correspond to transect samples shown in Figure 2.

5 


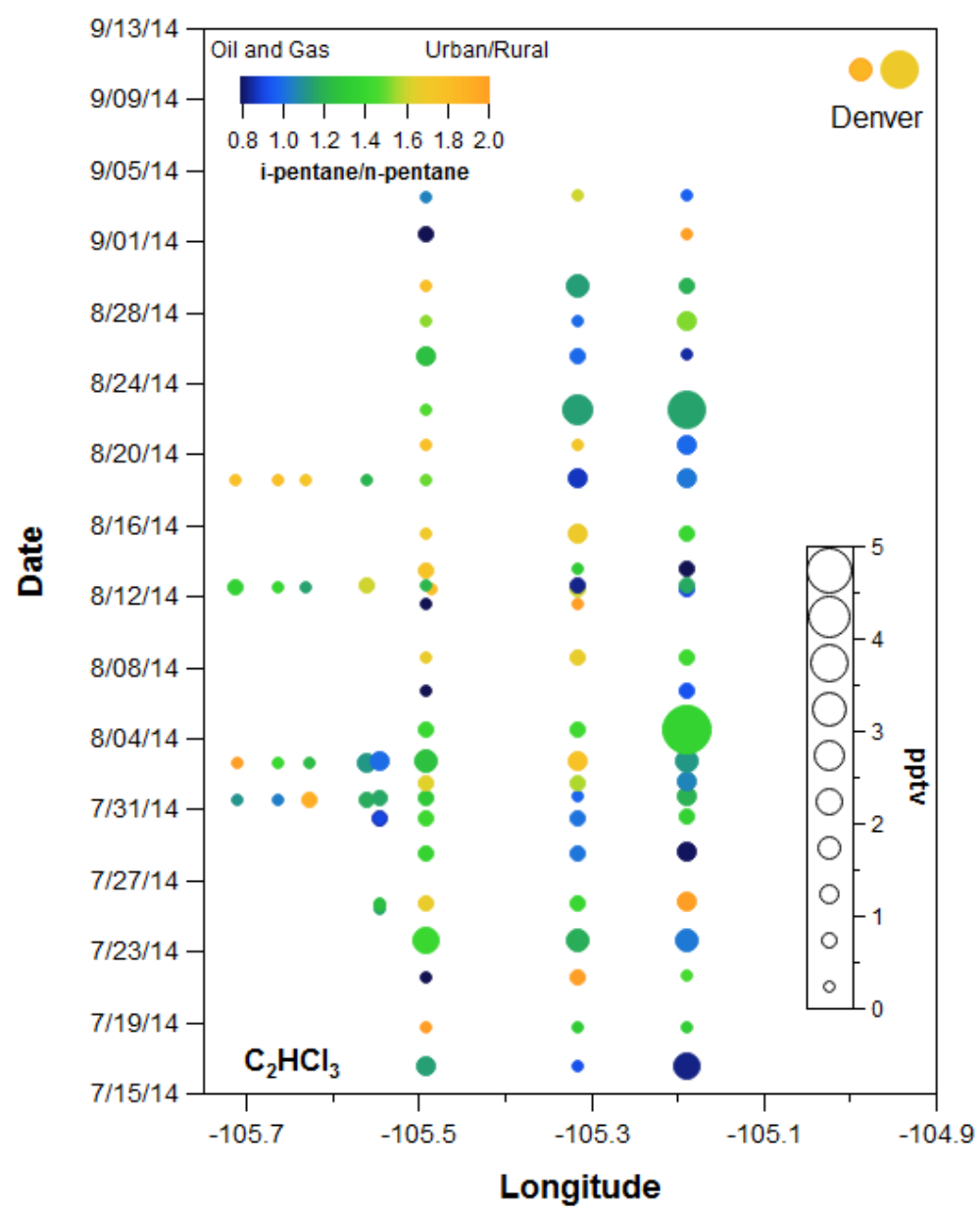

Figure S3f. VOC canister data plotted by longitude and date with $\mathrm{C}_{2} \mathrm{HCl}_{3}$ mixing ratio represented by the size of each point and the i- to n-pentane represented by the colour. Locations correspond to transect samples shown in Figure 2. 


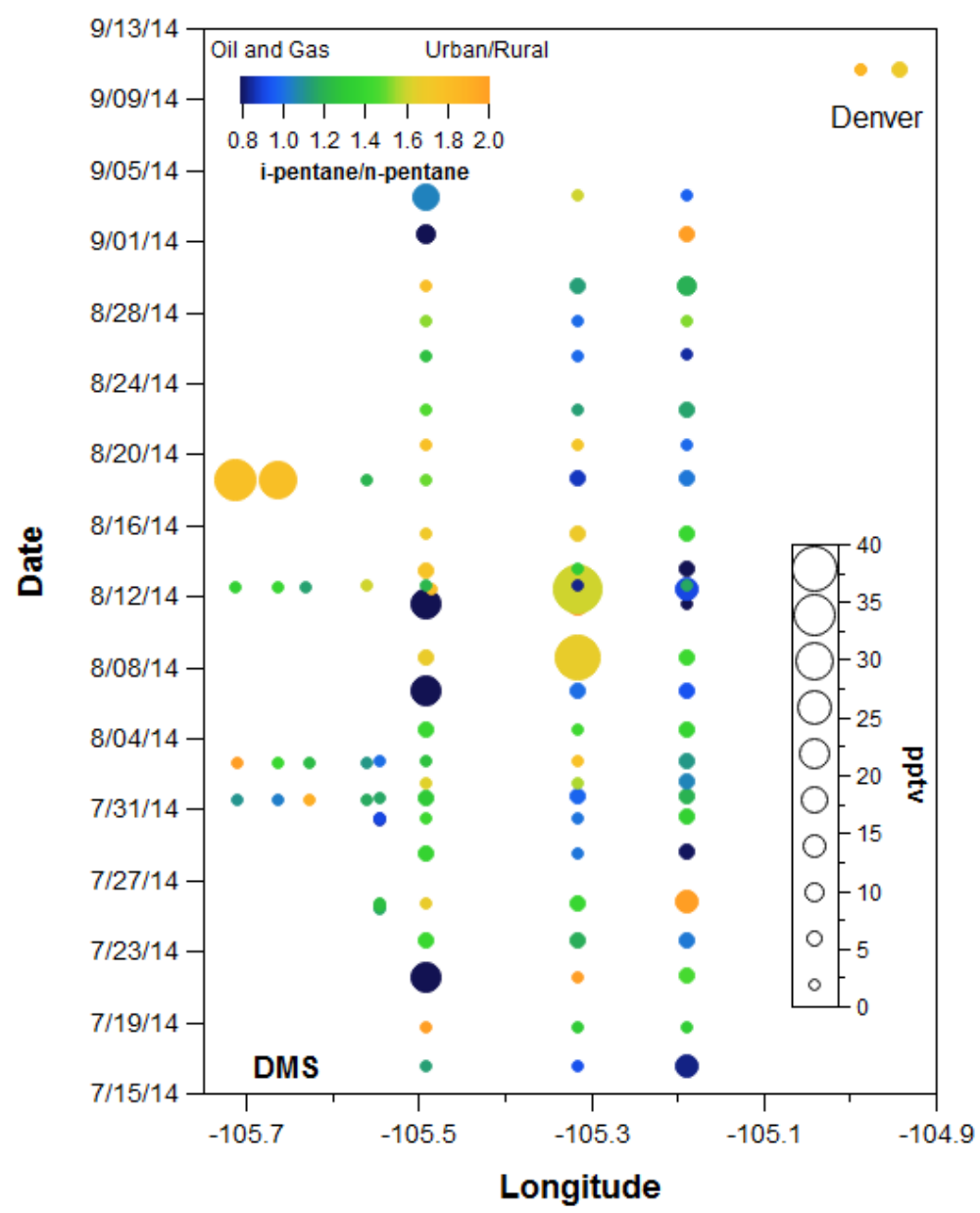

Figure S3g. VOC canister data plotted by longitude and date with DMS mixing ratio represented by the size of each point and the i- to n-pentane represented by the colour. Locations correspond to transect samples shown in Figure 2. 


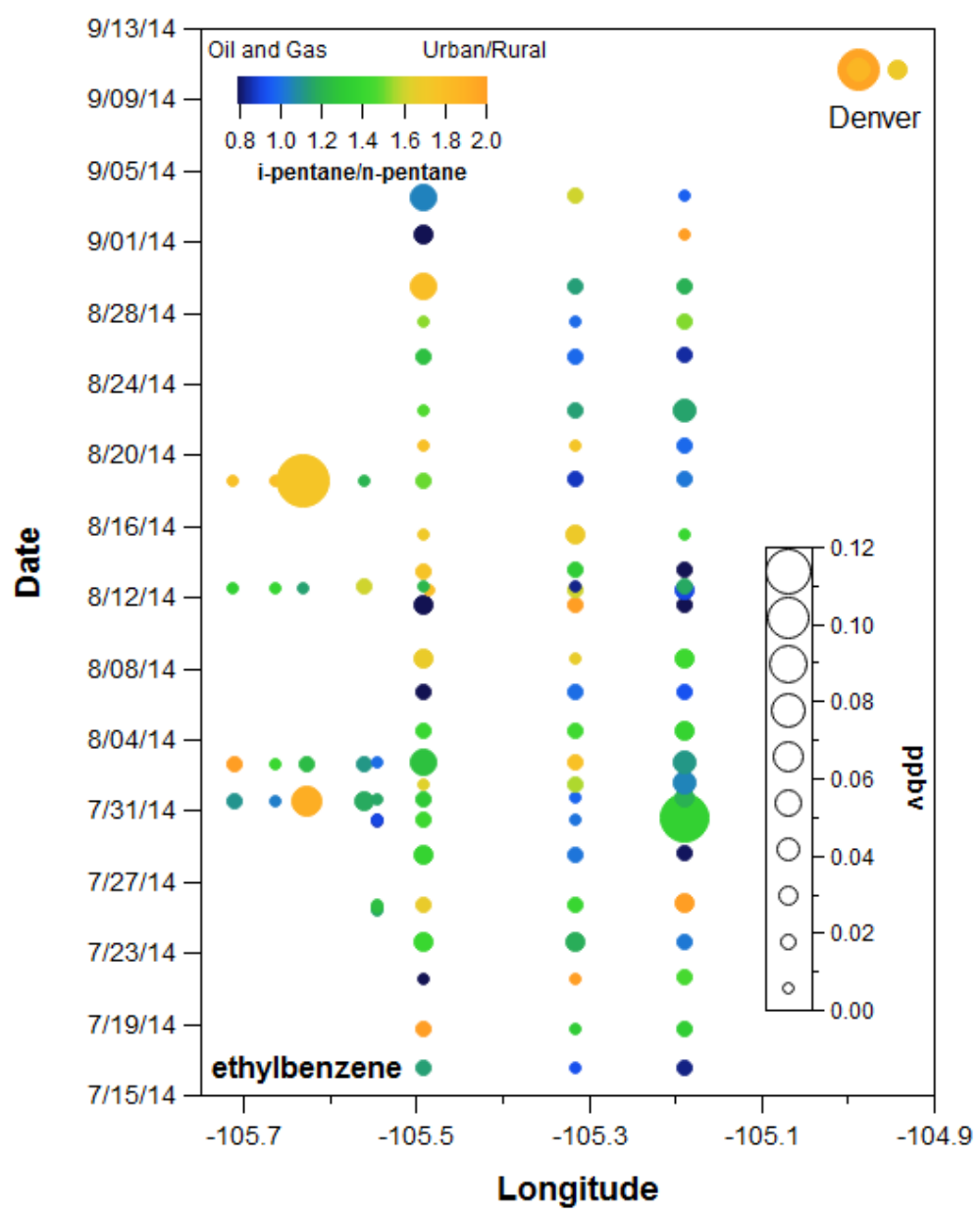

Figure S3h. VOC canister data plotted by longitude and date with ethylbenzene mixing ratio represented by the size of each point and the i- to n-pentane represented by the colour. Locations correspond to transect samples shown in Figure 2. 


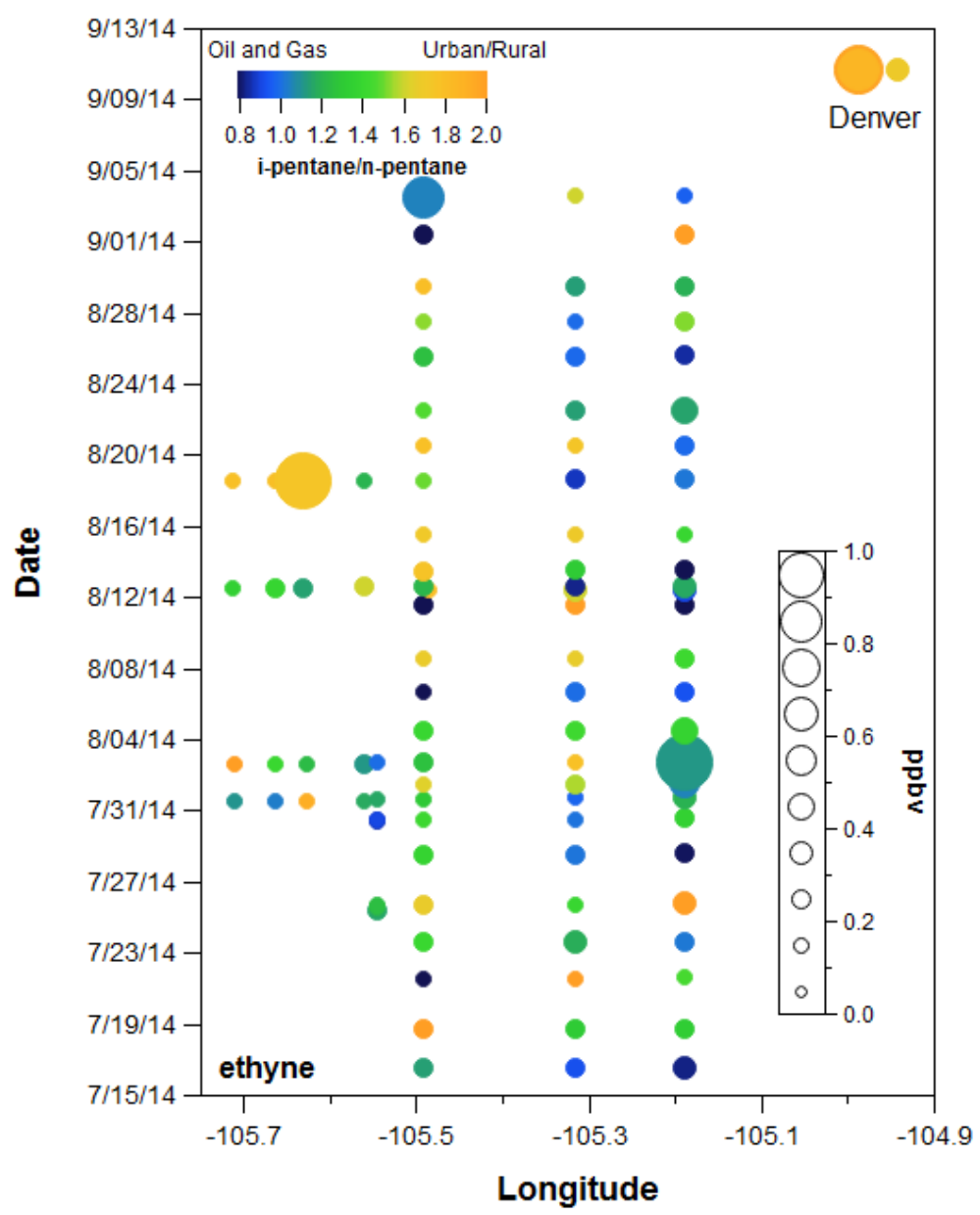

Figure S3i. VOC canister data plotted by longitude and date with ethyne mixing ratio represented by the size of each point and the i- to n-pentane represented by the colour. Locations correspond to transect samples shown in Figure 2. 


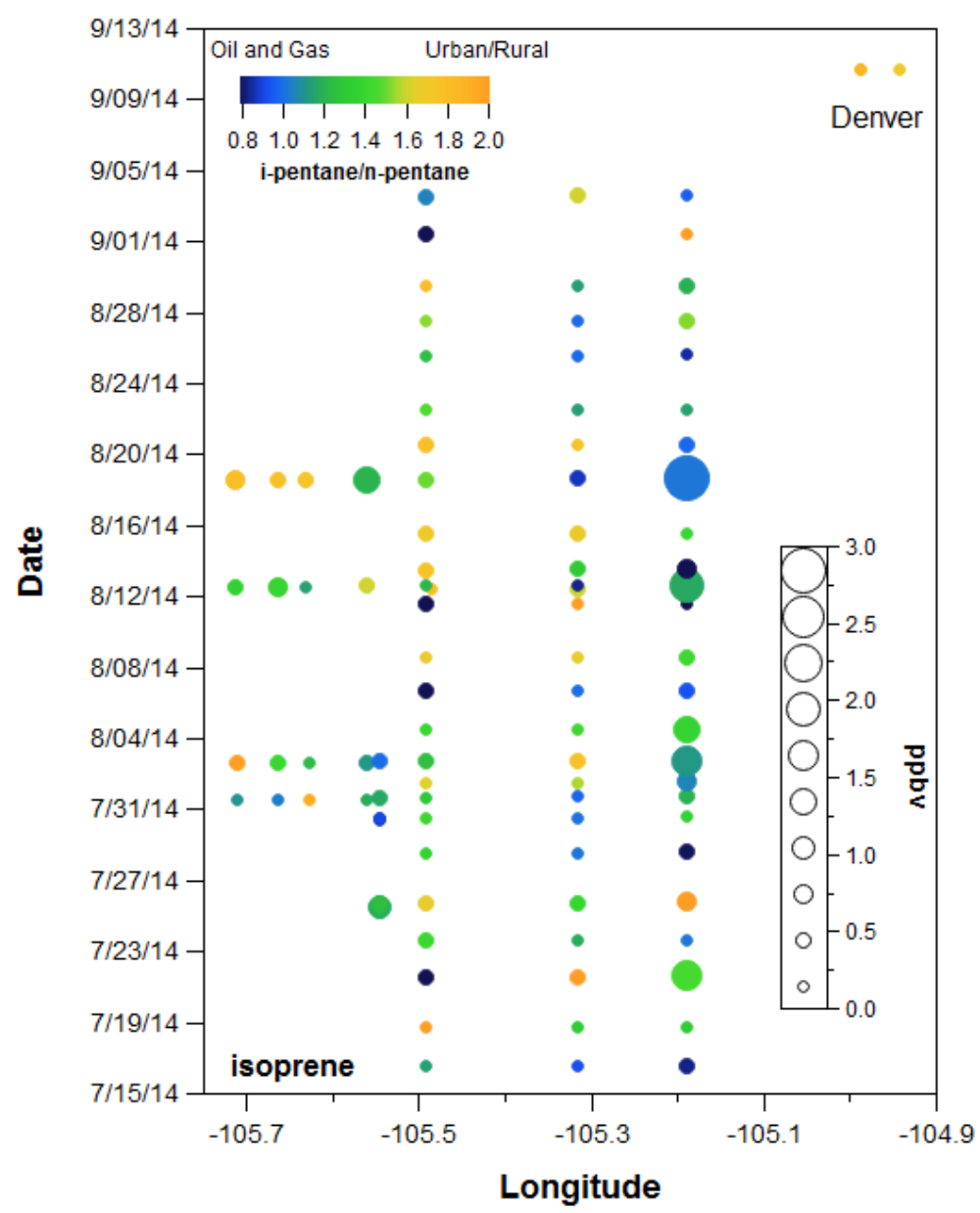

Figure S3j. VOC canister data plotted by longitude and date with isoprene mixing ratio represented by the size of each point and the i- to n-pentane represented by the colour. Locations correspond to transect samples shown in Figure 2. 


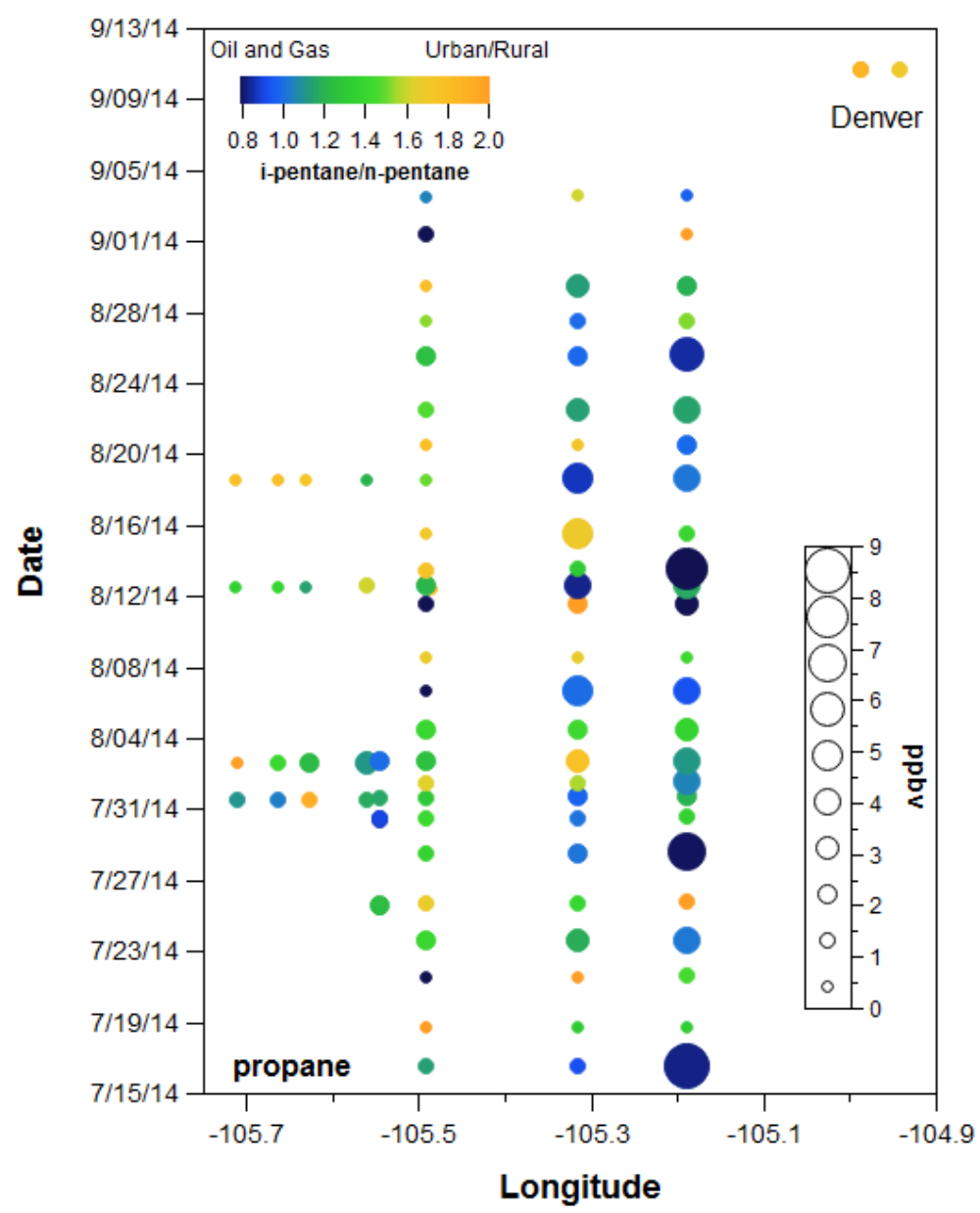

Figure S3k. VOC canister data plotted by longitude and date with propane mixing ratio represented by the size of each point and the i- to n-pentane represented by the colour. Locations correspond to transect samples shown in Figure 2. 


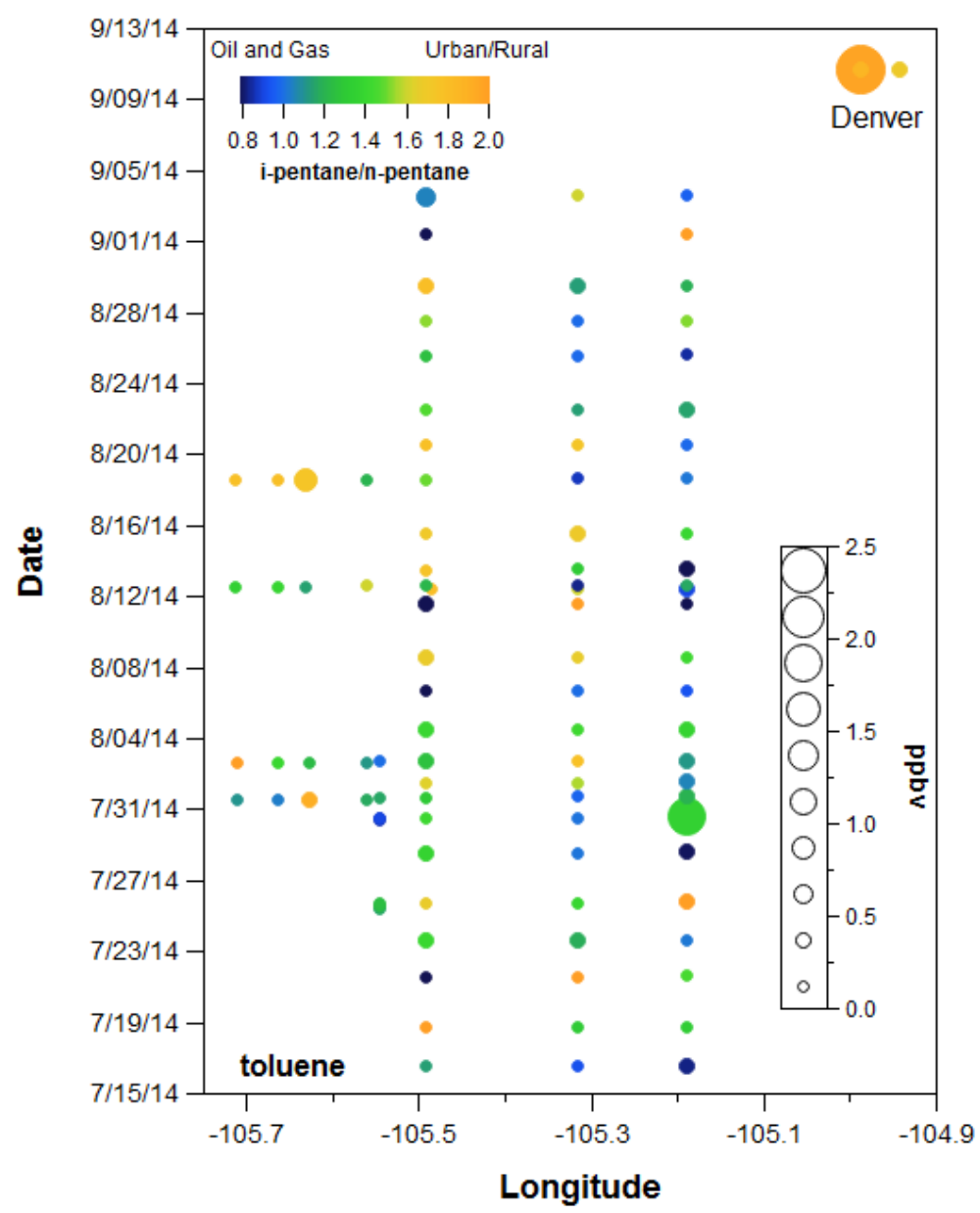

Figure S3I. VOC canister data plotted by longitude and date with toluene mixing ratio represented by the size of each point and the i- to n-pentane represented by the colour. Locations correspond to transect samples shown in Figure 2. 


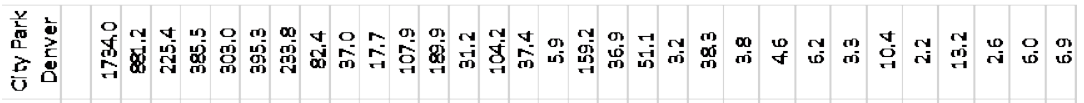

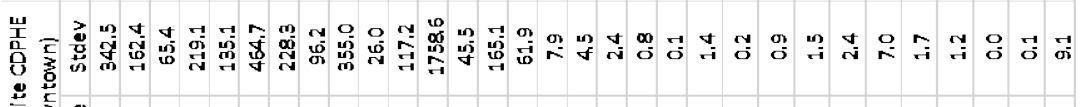

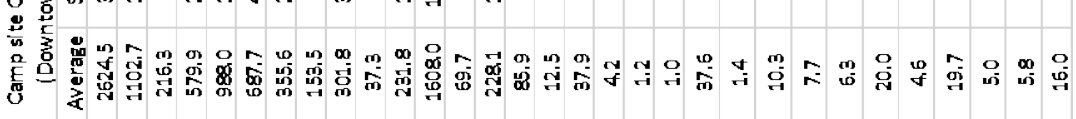
总

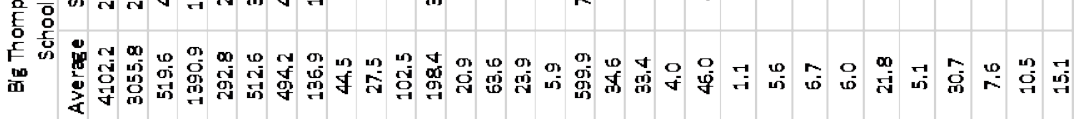

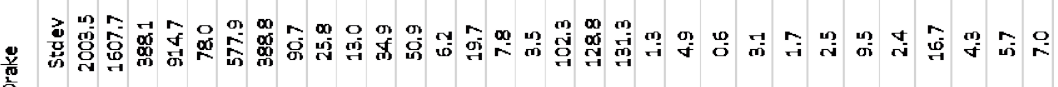
满

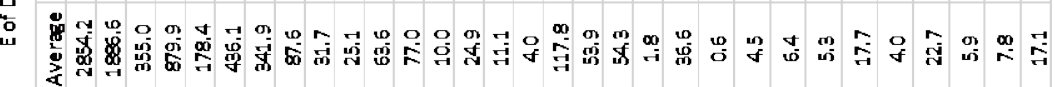

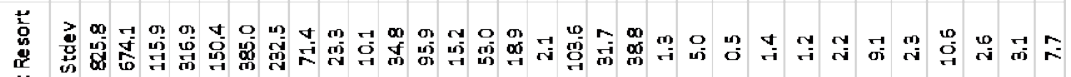

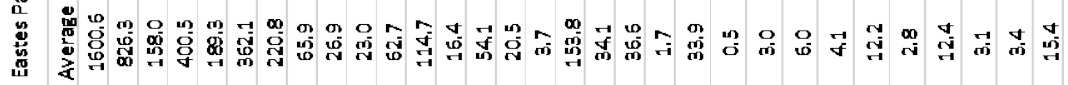

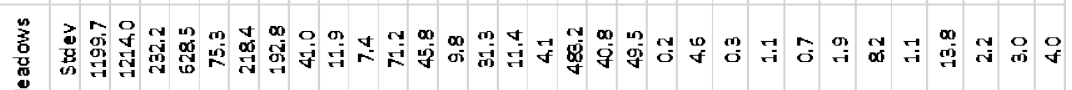

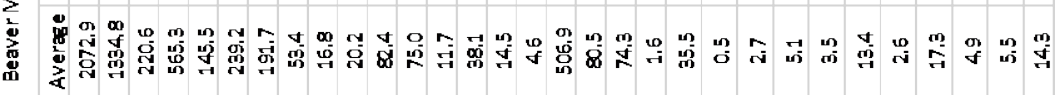

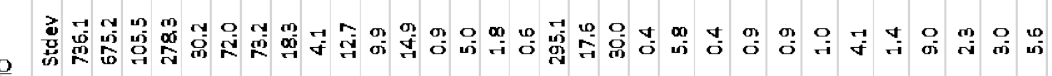
$\sum_{\substack{x\\}}$

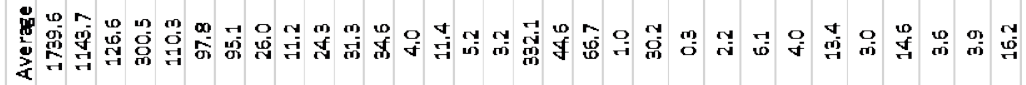

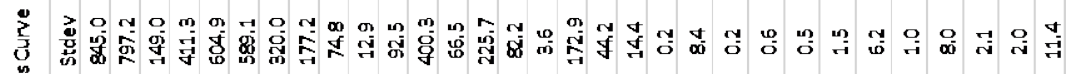

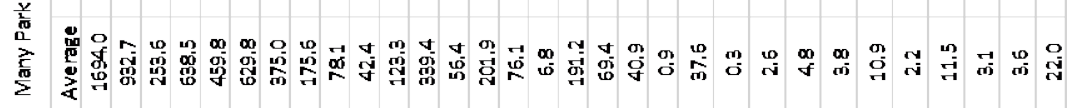

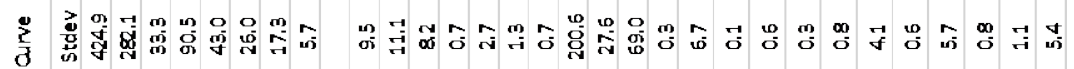

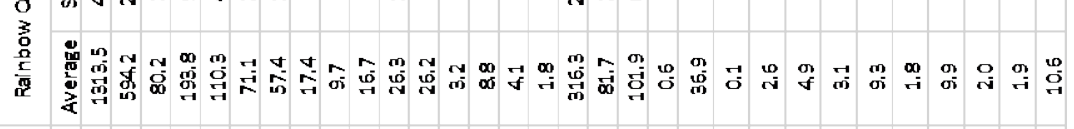

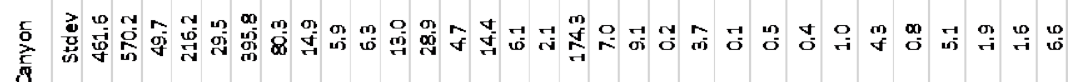
茛

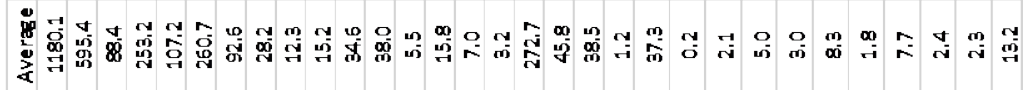

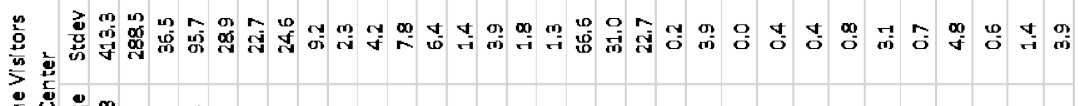

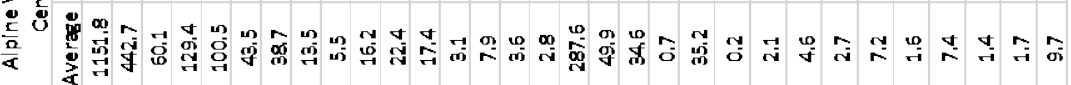

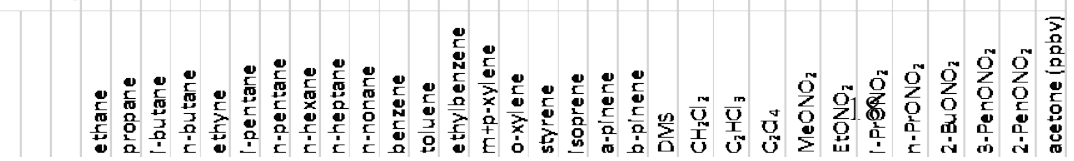


Table S1: Statistics of VOCs measured in transect samples during FRAPPE by site.

\section{References}

5 Abeleira, A., Pollack, I. B., Sive, B., Zhou, Y., Fischer, E. V. and Farmer, D. K.: Source characterization of volatile organic compounds in the Colorado Northern Front Range Metropolitan Area during spring and summer 2015, J. Geophys. Res. Atmospheres, 122(6), 2016JD026227, doi:10.1002/2016JD026227, 2017.

Bertman, S. B., Roberts, J. M., Parrish, D. D., Buhr, M. P., Goldan, P. D., Kuster, W. C., Fehsenfeld, F. C., Montzka, S. A. and Westberg, H.: Evolution of alkyl nitrates with air mass age, J. Geophys. Res. Atmospheres, 100(D11), 22805-22813, doi:10.1029/95JD02030, 1995

Koppmann, R., Johnen, F. J., Khedim, A., Rudolph, J., Wedel, A. and Wiards, B.: The influence of ozone on light nonmethane hydrocarbons during cryogenic preconcentration, J. Geophys. Res. Atmospheres, 100(D6), 11383-11391, doi:10.1029/95JD00561, 1995.

Russo, R. S., Zhou, Y., Haase, K. B., Wingenter, O. W., Frinak, E. K., Mao, H., Talbot, R. W. and Sive, B. C.: Temporal 15 variability, sources, and sinks of C1-C5 alkyl nitrates in coastal New England, Atmos Chem Phys, 10(4), 1865-1883, doi:10.5194/acp-10-1865-2010, 2010.

Sive, B. C.: Atmospheric Nonmethane Hydrocarbons: Analytical Methods and Estimated Hydroxyl Radical Concentrations, University of California, Irvine., 1998.

Sive, B. C., Zhou, Y., Troop, D., Wang, Y., Little, W. C., Wingenter, O. W., Russo, R. S., Varner, R. K. and Talbot, R.:

20 Development of a Cryogen-Free Concentration System for Measurements of Volatile Organic Compounds, Anal. Chem., 77(21), 6989-6998, doi:10.1021/ac0506231, 2005.

Zhou, Y., Shively, D., Mao, H., Russo, R. S., Pape, B., Mower, R. N., Talbot, R. and Sive, B. C.: Air Toxic Emissions from Snowmobiles in Yellowstone National Park, Environ. Sci. Technol., 44(1), 222-228, doi:10.1021/es9018578, 2010. 